\title{
Ecologists seek flexible protection rules
}

[WASHINGTON] The Clinton administration last week formalized its controversial 'no surprises' policy under which landowners who take steps to preserve natural habitat are guaranteed that they will not incur additional expense or obligations under species protection laws. Scientists, meanwhile, are pressurizing lawmakers to correct what they see as flaws in the policy.

The Endangered Species Act (ESA) allows landowners to 'take', or harm, some protected animals or plants in exchange for developing Habitat Conservation Plans (HCPs) that improve the species' overall chance of survival. About 225 such plans are already approved and 200 more are planned.

The interior secretary, Bruce Babbitt, has pushed HCPs as a way of involving private property owners in species protection, as half of the more than 1,000 species considered at risk of extinction are exclusively on private land. In 1994 he began promising landowners that there would be "no surprises" once an $\mathrm{HCP}$ was approved; the plans would be binding, in some cases for as long as 100 years.

Last week the Department of Interior codified 'no surprises' as a formal policy. But the policy has been criticized (see Nature 386, 530 ; 1997) because it does not allow for changing circumstances or new scientific

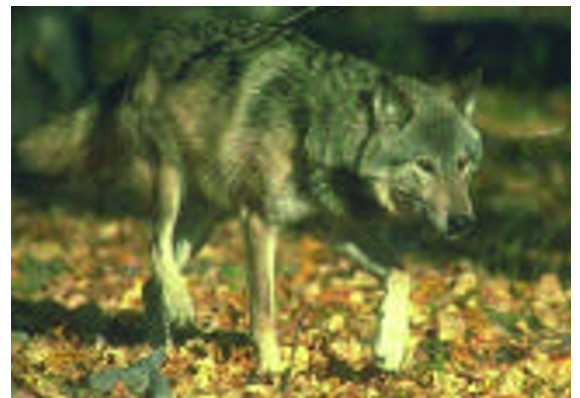

The grey wolf: prominent on 'endangered' list.

information about an endangered species.

Last month, 17 leading ecologists restated those and other worries in a letter to four senators who have introduced legislation to reauthorize the ESA. The authors propose "a few crucial amendments to make the [bill] more scientifically credible". They ask for assurances on stable funding for landowner incentive programmes that may require government spending, and for HCPs to be adjusted if they are not working.

They also call for the removal of two provisions from the bill: the requirement for independent scientific review of all listing decisions "even though many such decisions generate little or no scientific controversy", and the requirement for a detailed economic analysis of recovery measures.

The letter's main authors, GaryMeffe of the University of Florida and Stuart Pimm of the University of Tennessee, were joined by the ecologists Edward O. Wilson of Harvard, Paul Ehrlich ofStanford, Thomas Eisner of Cornell, Peter Raven, and two former presidents of the Ecological Society of America, Ronald Pulliam of the University of Georgia and Gordon Orians of the University of Washington.

Several policy initiatives announced with the 'no surprises' regulation suggest that the Interior Department is taking the criticisms seriously. The initiatives call for "expanded use of adaptive management for all HCPs", the establishment of clear biological goals for the plans, and improved scientific monitoring. The department is also to consider limiting the duration of some HCPs. Draft guidances for these initiatives are expected to be published within the next two weeks.

If the new legislation is to succeed, the trick will be to make the 'no surprises' policy flexible while still assuring landowners that they will not be surprised. Debate about ESA reauthorization is at present deadlocked, with both property rights advocates and environmentalists unhappy with the bill introduced by Dirk Kempthorne (Republican, Idaho) and three other senators.

TonyReichhardt

\section{Boost to biodiversity research 'would strengthen US economy'}

[WASHINGTON] Biodiversity research in the United States should be boosted because it will lead to a healthier environment which will, in turn, strengthen the nation's economy, an influential panel of scientists says.

In a report requested last year by President Bill Clinton - and to be delivered next month - the

President's Council of Advisors on Science and Technology (PCAST) says that spending on biodiversity research should grow from $\$ 460$ million a year to $\$ 660$ million over the next three years. The report was prepared for PCAST by a panel chaired by Peter Raven, the director of the Missouri Botanical Garden in St Louis.

"I think that the logic of [the report] is compelling," says Murray Gell-Mann of the Santa Fe Institute in New Mexico, a member of PCAST and of Raven's panel. He adds that the report's suggested "synergy" between the environment and the economy "will resonate with people, including members of Congress".
In the recent past, the discipline has been attacked by conservatives in Congress, who see the gathering of information on biodiversity as a threat to landowners' property rights.

As a result of such attacks, for example, the National Biological Survey was disbanded by the Congress in 1995, and the Senate has declined to ratify the international Convention on Biological Diversity, the agreement signed at the Earth Summit in Rio de Janeiro in 1992, which has already been ratified by 161 other countries.

The report emphasizes the relationships between biodiversity conservation, a healthy environment and a strong economy. It also calls for the development of better computer networks and databases for information about plant and animal species.

Five major funding proposals are suggested by the panel for consideration by the dozen or so federal agencies involved in biodiversity research, over the next three years. They are: - an increase from $\$ 74$ million to $\$ 130$ million a year in funding for taxonomists to discover and describe new species;

- an increase from $\$ 300$ million to \$355 million for research and monitoring of ecosystems; - \$24 million in new money for social science research, chiefly at the National Science Foundation, to improve estimates of the economic value of sound environmental management; - "a minimum of $\$ 40$ million a year" to develop a 'next generation' National Biological Information Infrastructure on which information about species can be stored and accessed; - spending on environmental education to rise from $\$ 72$ million to $\$ 87$ million, mostly to train 10,000 schoolteachers a year about environmental science.

The recommendations are largely based on discussions with government scientists about their resource needs, and these scientists are pleased about the outcome. "For us, this is a breath of fresh air," says Michael Ruggiero, a senior ecologist at the Biological Resources Division of the United States Geological Survey, which has absorbed the National Biological Survey.

Consideration by PCAST,

Ruggiero says, "may be the highest level at which this issue has ever been addressed".

If previous PCAST studies are any guide, the Raven panel is likely to have significant influence on next year's budget requests from the agencies involved. But changing Congress's approach will be a larger challenge.

"There's a lack of general appreciation of what scientists are coming to understand about connections between the loss of biodiversity and the things that people care about," concedes Jane Lubchenco of Oregon State University, a panel member. The report, she adds, is "just one stage" in changing that appreciation.

ColinMacilwain 